\title{
PROGRAM TRAINING E DEVELOPMENT BERBASIS SPIRITUALITAS
}

\author{
Siswanto \\ Fakultas Ekonomi Universitas Islam Negeri (UIN) Malang \\ J1. Gajayana No. 50, Telepon (0341) 558881, Fax. (0341) 558881, \\ E-mail: feuinmlg@yahoo.co.id
}

\begin{abstract}
This paper attempts to explain the role of spirituality in workplace to reach highly organization performance. The currently challenge both profit and non-profit organization is how to develop human resource. That's so urgent because it's a valuable asset. Three ways to develop human resource consists of training and development, organization development, and career development. The intent of this paper is to integrate spirituality in training $\mathcal{E}$ development program. Spirituality in workplace has relationship with attitude and organization behavior dimension (Milliman et.al. 2003). Dimension of organization behavior encompass organization commitment, intention to quit, intrinsic work satisfaction, job involvement, and organization-based self-esteem. The paper concludes that training $\mathcal{E}$ development based-spirituality will contribute to long term behavior/attitude change.
\end{abstract}

Keyword: human resource development program, training $\mathcal{E}$ development, spirituality

Wacana dan diskusi tentang program pengembangan sumberdaya manusia yang berkembang saat ini adalah memasukkan nilai-nilai spiritulitas dalam program training $\mathcal{E}$ development. Spiritualitas merupakan kebutuhan penting yang tidak dapat ditunda dalam kehidupan yang kosmopolit. Seiring dengan pemenuhan kebutuhan-kebutuhan yang bersifat materi, pemenuhan kebutuhan spiritualitas menjadi sebuah tuntutan yang tidak dapat dielakkan. Sebagaimana disinyalir oleh Maslow ketika mengidentifikasi kebutuhan manusia yang bertingkat dalam teori hirarki kebutuhan. Dalam teori hirarki kebutuhan, spiritualitas merupakan bagian dari kebutuhan aktualisasi diri yang menjadi puncak kebutuhan manusia. Pemenuhan kebutuhan terhadap nilai-nilai spiritualitas mutlak diperlukan dalam menjalankan kehidupan bermasyarakat dan berorganisasi. Hal ini mendorong pihak owner organisasi bisnis perlu memenuhi kebutuhan dan mengaplikasikannya dalam organisasi.

Hubungan antara kebutuhan dan pemuasan kebutuhan dapat dilihat dalam skema 1.1. Kebutuhan yang dirasakan oleh manusia menuntut suatu pemenuhan. Dorongan untuk memenuhinya termanifestasikan dalam perilaku individu yang bersangkutan. Untuk melihat 
bagaimana peran spiritualitas dalam kehidupan, di Amerika Serikat, tahun 1994 pernah dilakukan sebuah penelitian. Penelitian tersebut menunjukkan bahwa 76\% dari orang amerika yang telah berusia lanjut menyatakan bahwa agama merupakan sesuatu yang sangat penting bagi kehidupan mereka dan 52\% dari orang Amerika yang berusia lanjut mengikuti layanan agama secara rutin. Agama juga sangat penting untuk mengatasi permasalahan-permasalahan yang dihadapi manusia, terutama sakit. Banyak pasien medis menganggap keyakinan dan ritual agama merupakan cara yang tepat untuk menyembuhkan penyakit fisik, dan lebih dari 40\% menyatakan bahwa agama merupakan faktor yang paling penting bagi kesembuhan mereka (Makki, 2005).

Trend masyarakat untuk kembali kepada nilai spiritualitas dan agama merambah seluruh lapisan masyarakat. Maraknya aktivitas spiritualitas masyarakat terutama di perkotaan menurut Komarudin Hidayat dipicu oleh empat sebab, yakni; (1) sebagai sarana pencarian makna hidup (2) sebagai sarana pergulatan dan pencerahan intelektualitas (3) sebagai sarana terapi psikologis (4) sarana untuk mengikuti trend dan perkembangan wacana keberagamaan. Berbagai gerakan sufisme saat ini banyak ditemui dan diikuti masyarakat perkotaan, seperti Paramadina, Tazkia Sejati, ICNIS, IIMAN, dan pengajian yang diselenggarakan oleh ustadz Haryono, Aa Gym, ustadz Arifin Ilham selalu dibanjiri oleh masa. 
Gambar 1.1. Proses Kebutuhan Aktif - Pemuasan Kebutuhan (Desimone, et., al. 2005)

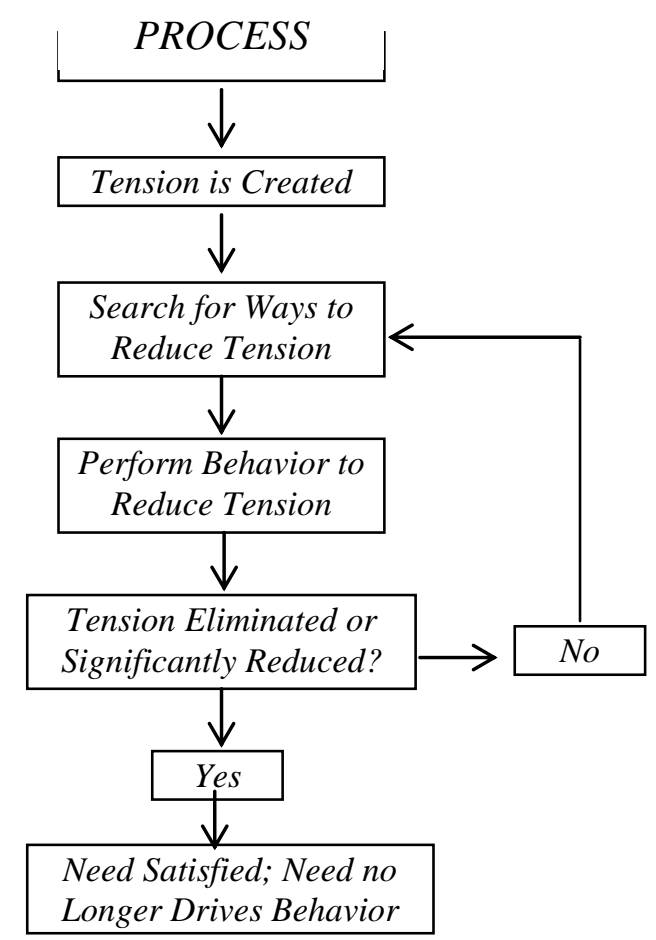

\section{PROGRAM PENGEMBANGAN SUMBERDAYA MANUSIA}

Program pengembangan sumberdaya manusia dapat dibagi menjadi 3 fungsi utama, yakni; training \& development, organization development dan career development (Desimone, et., al.). Ketiga program tersebut merupakan upaya organisasi memberdayakan karyawan agar mencapai kinerja tertinggi sehingga dapat memberikan value added bagi perusahaan.

Training \& development memiliki peran penting dalam rangka meningkatkan produktivitas dan kinerja organisasi. Fernald et.al. (1999) menemukan bahwa rendahnya investasi perusahaan yang dialokasikan untuk training menyebabkan perusahaan yang masuk kategori small business di USA tertinggal dari kompetitornya. Berdasarkan hasil pengamatan dan kajian data, lebih lanjut Fernald et.al. (1999) menyatakan implikasi bagi pihak manajemen dan pengambilan keputasan antara lain; (1) semakin ketatnya persaingan usaha dan adanya perkembangan teknologi yang pesat memerlukan tenaga kerja yang terampil (2) semakin luasnya jasa layanan yang menuntut pekerja yang memiliki pengetahuan yang memadai (3) sangat mendesak kebutuhan pelatihan untuk meningkatkan keunggulan kompetitif perusahan skala small business (4) diperlukan metode pelatihan yang lebih variatif. 
Organization development merupakan proses yang dilakukan untuk meningkatkan efektivitas organisasi dan keadan serta kesejahteraan pegawai melakukan kebijakan terencana melalui penerapan konsep ilmu perilaku. Pengembangan organisasi menekankan perubahan organisasi baik secara mikro maupun makro. Perubahan makro berarti pencapaian efektivitas organisasi yang paling tinggi, sedangkan perubahan mikro merupakan perubahan yang berhubungan dengan perubahan individu, kelompok kecil dan tim.

Career development merupakan proses yang dialami seorang individu yang bergabung dalam organisasi sebagai hasil evaluasi kemajuan kegiatan dan pekerjaan yang telah dilaksanakan. Pengembangan karir meliputi dua hal, yakni perencanaan karir (career planning) dan manajemen karir (career management). Perencanaan karir itu sendiri merupakan proses yang dilalui oleh individu untuk mengidentifikasi dan mengambil langkah-langkah untuk mencapai tujuan karirnya. Sedangkan manajemen karir merupakan proses yang dilakukan oleh organisasi untuk memilih, menilai, menugaskan dan mengembangkan para karyawannya guna menyediakan suatu kumpulan orang-orang yang kompeten untuk memenuhi kebutuhan masa depan.

\section{Training \& Development}

Training \& development salah satu kegiatan dalam pengembangan sumberdaya manusia. Program Training \& development digunakan untuk meningkatkan dan mengembangkan keterampilan, pengetahuan dan sikap para pekerja. Program Training \& development lazim dilakukan, baik oleh organisasi bisnis maupun organisasi non bisnis. Fokus dan aktivitas antara training dengan development seringkali dibedakan.

Aktivitas training dilakukan untuk memberikan pengetahuan dan keterampilan, perubahan sikap atau sikap tertentu yang diharapkan sesuai dengan jenis pekerjaan yang sudah tertentu pula. Sedangkan kegiatan pengembangan (development activities) dilakukan untuk mempersiapkan para pekerja terkait dengan tanggung jawab di masa yang akan datang.

Kegiatan training \& development diawali ketika pertama kali karyawan masuk dalam organisasi. Saat itu staf Human Resource Development (HRD) melakukan orientasi karyawan dan pelatihan skill mereka. Masa orientasi karyawan ini akan diperkenalkan nilai-nilai yang dianut oleh organisasi tersebut, menunjukkan keterkaitan hubungan kerja, dan belajar bagaimana untuk melakukan pekerjaan yang akan dihadapi. Selanjutnya akan diberikan pelatihan keterampilan terkait dengan pekerjaan yang akan dihadapi. 
Setelah dianggap layak, karyawan tersebut diberikan program-program pengembangan. Program pengembangan meliputi coaching dan counseling. Dalam kegiatan coaching, seorang karyawan secara bertahap dapat menerima tanggung jawab penuh terkait dengan pekerjaan yang dilakukan. Sedangkan counseling process meliputi aktivitas yang dilakukan oleh staf HRD untuk menangani pekerja yang memiliki masalah pribadi yang mengganggu pencapaian tujuan organisasi.

Program training \& development memerlukan perencanaan yang matang dalam pencapaian efektivitasnya. Rae $(2002 ; 1)$ berpendapat bahwa perencaan kegiatan training \& development perlu memperhatikan beberapa faktor berikut, antara lain; (1) tipe organisasi, (2) ukuran organisasi, (3) distribusi para pekerja, group dan tim kerja, (4) Susunan peran pekerjaan dan jumlah peran pekerja dalam susunan pekerjaan tersebut, (5) kebutuhan para pekerja pada semua level pekerjaan, (6) inisiatif khusus seperti komitmen pada manajemen kualitas, prioritas pada layanan pelanggan, syarat tingkat pendidikan.

\section{Peran Trainer dalam Program Training \& Development}

Salah satu faktor penting yang menunjang keberhasilan training $\mathcal{E}$ development adalah faktor trainer. Seorang trainer memiliki peran sebagai maintainer dan change agent (Analoui; 1994). Sebagai maintainer seorang trainer berperan sebagai pengelola kondisi yang sedang dihadapi seorang trainee yang cenderung status quo menuju kondisi yang lebih dinamis. Sebagai agent of change, seorang trainer cenderung mengutamakan proses pengembangan karyawan daripada terlibat banyak dalam sesuatu yang bersifat teknis.

Seorang trainer dituntut memiliki keterampilan dan kompetensi yang memadai guna mendukung keberhasilan training \& development. Boydell (dalam Analoui; 1994) berpendapat bahwa setiap trainer hendaknya memiliki 3 keterampilan dan kompetensi, yakni; (1) kompetensi sebagai praktisi dibidangnya, (2) kompetensi di bidang kepememimpinan, (3) kompetensi di bidang organisasi. Hasil riset Analoui yang dilakukan di Zimbabwe dan India pada tahun 1989 menunjukkan bahwa peran, keterampilan dan kompetensi memiliki kontribusi yang relevan terhadap keberhasilan trainer.

Dalam rangka mencapai keberhasilan pelatihan, lebih lanjut Boydell (dalam Analoui; 1994) menyarankan trainer untuk memperhatikan beberapa hal berikut; (1) selalu meng-update pengetahuan, dan keterampilan teknis dan hubungan sosial, (2) meningkatkan kemampuan untuk memahami kebutuhan, pengetahuan, gaya dan sikap trainee, (3) memiliki kemampuan

\section{Created with}


yang cukup terhadap tugas, peran, budaya organisasi, politik dan lingkungan trainee (4) memiliki pengetahun untuk memahami keunikan yang dimiliki oleh trainee (5) memiliki pengetahuan yang memadai terhadap isu-isu penting dalam organisasi.

\section{Tujuan Akhir Program Training \& Development}

Perubahan sikap dan perilaku yang berjangka panjang berasal dari perubahan dari dalam. Hawley (1993, dalam Neck \& Milliman, 1994) menyatakan bahwa tujuan penting memasukkan nilai-nilai spiritualitas di tempat kerja agar para karyawan memiliki sikap positif dan melihat realitas dari perspektif positif. Milliman et. al. melakukan penelitian peran nilai spiritualitas di tempat kerja terhadap sikap dan perilaku individu. Perilaku individu tersebut dipilah menjadi 3 tingkatan, yakni tingkat individual, tingkat kelompok dan tingkat organisasional. Berdasarkan penelitian yang oleh Milliman et.al. (2003) dengan sampel 200 pegawai yang sedang mengambil studi MBA di Amerika bagian barat daya menunjukkan bahwa;

1. Nilai-nilai spiritualitas seseorang memiliki hubungan yang positif terhadap komitmen organisasi dari orang tersebut pada ketiga level

2. Nilai spiritualitas memiliki hubungan negatif terhadap hasrat karyawan untuk keluar/ berhenti dari pekerjaan

3. Nilai spiritualitas di tempat kerja memiliki hubungan yang positif terhadap kepuasan kerja pada level individual dan kelompok

4. Nilai spiritualitas di tempat kerja memiliki hubungan yang positif terhadap kertelibatan dalam pekerjaan pada level individu dan kelompok

5. Nilai spiritualitas di tempat kerja memiliki hubungan yang positif terhadap OBSE (Organization Based Self-Esteem) pada level kelompok dan organisasi

Berdasarkan hasil penelitian tersebut, spiritulitas memiliki peran penting terhadap perubahan sikap dan perilaku karyawan. Guna mendukung perubahan dari dalam yang berjangka panjang, Covey (1994) memasukkan tiga faktor penting pendukung perubahan internal, yakni kesadaran, keinginan dan keterampilan. Model-model pelatihan dan pengembangan SDM dengan menyentuh nilai dasar dan paradigma berfikir memiliki dampak besar perubahan dari dalam. Perubahan dari dalam pada dasarnya merupakan perubahan kebiasaan dan perilaku yang telah sekian lama dilakukan berulang-ulang. Untuk merubahnya diperlukan ketiga faktor tersebut. 


\section{APAKAH SPIRITUALITAS ITU?}

Manusia terdiri atas tubuh, pikiran, emosi dan spirit ${ }^{1}$. Maslow (1970 dalam Howard 2002) menyebut dengan "hidden yearning" sebagai indikator penting dari spiritualitas. Spiritualitas meliputi cara seorang individu untuk memahami kehidupan dengan memanfaatkan kemampuan batin yang dimiliki. Spiritualitas memiliki beberapa terminologi yang sering digunakan antara lain; kebenaran, kasih sayang, pelayanan, kegembiraan, kedamaian, ketulusan. Spiritualitas juga meliputi kesadaran diri (self-awerness) dan kebersamaan. Spiritulitas meliputi pula gabungan antara filosofi dasar dari kehidupan kita, nilai (value) yang kita lakukan dan jalani.

Neil (1997, dalam Cacioppe, 2000) mendefinisikan spiritualitas di tempat kerja merupakan;

“... about integrity, being true to oneself, and telling the truth to others. Workplace spirituality refers to an individual's attempts to live his or her values more fully in workplace. Or it can refer to the ways in which organizations structure themselves to support the spiritual growth of employees".

Pendapat tersebut menegaskan bahwa spiritualitas dapat diterapkan pada semua level dalam organisasi, baik secara personal berhubungan interaksi seseorang dengan orang lain, maupun secara organisasional ketika berinteraksi dengan para karyawan, pelanggan maupun lingkungan.

Sedangkan menurut Mitroff dan Denton (1998 dalam Cacioppe, 2000), setelah melakukan interview 85 eksekutif senior dari devisi manajemen sumber daya manusia, mendefinisikan spritualitas;

" the basic desire to find ultimate meaning and purpose in one's life and to live in integrated life"

\section{Pemicu Gerakan Spiritualitas dalam Berbagai Aspek Kehidupan}

Spiritualitas merupakan sebuah gerakan antiklimaks dari hegemoni ideologi materialistis yang diwakili oleh negera barat. Perkembangan dan munculnya gerakan spiritual telah diprediksikan oleh John Naisbit dalam bukunya Megatrend 2000. Naisbit memprediksikan di abad-abad mendatang akan muncul new age movement atau gerakan new age. Karakteristik gerakan ini ditandai nilai-nilai spiritual yang meraka aplikasikan dalam

\footnotetext{
${ }^{1}$ Dalam kamus Bahasa Inggris Echols \& Shadily spirit memilik makna; ruh (jiwa), semangat, arwah. Sedangkan spiritual diberi arti bathin (rohani) dan keagamaan 
kehidupan. Beberapa pemicu munculnya gerakan new age di abad XXI antara lain; (1) Modernitas dinyatakan gagal dalam mewujudkan perbaikan-perbaikan yang dramatis, sebagaimana yang dinyatakan oleh pendukung fanatiknya (2) Ilmu pengetahuan modern memiliki kontribusi pada masalah-masalah sosial, lingkungan dan kejiwaan masyarakat modern dewasa ini seperti kelaparan, kerusakan lingkungan, kemiskinan dan lain sebagainya (3) Ilmu pengetahuan modern kurang mementingkan kebutuhan yang berdimensi spiritual dan lebih mementingkan atribut fisik individu.

Karena ketiga faktor tersebut menyebabkan jiwa manusia menjadi kosong. Dunia modern identitik dengan materalisme. Ideologi materialisme dan konsumerisme dikonsumsi dan ditawarkan kepada semua lapisan masyarakat. Kekosongon nilai spiritual dalam diri menyebabkan manusia bingung menentukan arah hidup, tujuan dia hidup dan bekerja, makna hidup yang dijalani, tingkat stress yang meningkat, bahkan di negara maju angka bunuh diri menunjukkan tren yang semakin meningkat.

Pada dasarnya nilai-nilai spiritualitas dapat diambil dari budaya dan agama. Namun demikian agama memiliki landasan yang kuat dalam mendorong nilai-nilai tersebut. Agama Islam sebagai agama memiliki konsepsi yang kukuh dalam mendorong nilai-nilai spiritual yang diaplikasikan dalam kehidupan. Sebab Agama Islam berisi tuntunan yang mengarahkan dan mengatur cara beramal (ibadah), berakhlak dan bermasyarakat (muamalah).

Spiritualitas meliputi segala perasaan, pikiran, pengalaman dan perilaku yang muncul dari proses mengidentifikasi, mengartikulasi, dan mentransformasi pada suatu keyakinan tertinggi yang diterima oleh seseorang. Para pakar di bidang agama menyatakan bahwa spiritualitas merupakan suatu pencarian atau perjalanan. Perjalanan dalam spiritualitas tersebut dijelaskan oleh Diana Butler Bass (1998), seorang profesor studi agama di Rhode College, sebagai sebuah perjalanan yang memiliki dua bentuk. Pertama, perjalanan kedalam (inner journey) terhadap kejiwaan, pertanyaan, dan upaya menggali hakikat diri serta sebuah misteri yang memiliki kekuatan transendental. Kedua, perjalanan keluar (outward journey) berupa upaya menghubungkan dan mengaplikasikan keyakinan yang dimiliki dengan tindakan dan perilaku.

Nilai-nilai spiritualiatas tidak hanya dilihat dalam kehidupan hubungan sosial masyarakat, namun dapat dilihat juga pada organisasi bisnis. Organisasi-organisasi bisnis sering mengadopsi nilai-nilai spritualitas untuk pengembangan organisasi. Pengembangan 
organisasi meliputi organisasi sebagai sistem dan organisasi sebagai organisme. Organisasi sebagai sebuah sistem memiliki perangkat untuk mencapai tujuan. Struktur dan desain organisasi mendukung nilai-nilai spiritualitasnya.

Dalam sebuah penelitian dengan metode meta analisis, setelah melakukan pendataan dan observasi hasil-hasil penelitian yang berhubungan dengan spiritualitas di tempat kerja, menemukan bahwa spiritualitas merupakan kebutuhan mendasar bagi karyawan yang sering tidak dipenuhi. Hal tersebut disebabkan adanya kekhawatiran perusahaan akibat persepsi negatif atas konotasi spiritualitas. Perusahan seringkali tidak menyadari kegunaan dari penerapan spiritualitas di tempat kerja (Leonard \& Biberman, 2007).

\section{Spiritualitas dan Kinerja Karyawan}

Hasil riset dan publikasi yang berhubungan dengan spiritualitas karyawan di tempat kerja semakin meningkat. Hal tersebut dapat dilihat dari publikasi-publikasi ilmiah yang berhubungan dengan tema tersebut (Shellenbarger, 2000 dalam Milliman et.al.,). Spiritualitas di tempat kerja telah menjadi topik utama bebeberapa majalah internasional seperti Business Week dan Fortune.

Heaton et.al., (2004) berpendapat bahwa memadukan manajemen dengan tinjauan spiritualitas memiliki peran untuk melakukan manajemen perubahan organisasi. Manajemen perubahan organisasi yang dimaksud yakni membantu menolong para karya memiliki target kinerja yang baru sehingga dapat meningkatkan performance dengan cepat dan efisien. Butts (1999) menyatakan bahwa beberapa dimensi spiritualitas ketika diintegrasikan di dunia kerja dapat meningkatkan kreativitas, penerimaan pada diri sendiri, harmonisasi organisasi dan sukses bisnis jangka panjang. Dimensi spiritualitas itu meliputi; ultimate values, ultimate human development, the art of transcendence, spiritual psychologies baik klasik maupun modern.

Spiritualitas mempengaruhi karyawan dan kinerja organisasi melalui beberapa cara (Neck \& Milliman, 1994), antara lain; (1) Spiritualitas dapat mengarahkan para karyawan pada sebuah pengalaman kesadaran pada tingkat tertinggi dan bahkan akan mampu meningkatkan kemampuan intuitif, (2) intiusi yang bersumber pada nilai spiritualitas dapat mendorong pencapai visi organisasi, (3) organisasi yang berorientasi pada spiritualitas di tempat kerja akan mendapati karyawan yang memiliki pengembangan dan pertumbuhan individu pada tingkat 
yang lebih tinggi, (4) nilai-nilai yang berdasarkan pada spiritualitas dapat meningkatkan tim kerja yang solid dan meningkatkan komitmen karyawan pada organisasi.

Untuk mengubah kognisi dan persepsi karyawan, perubahan ke arah spiritualitas, Neck dan Milliman menawarkan teori TSL (Thought Self-Leadership). TSL merupakan sebuah proses perubahan paradigma dan cara berpikir. Teori TSL merupakan pengembangan dari teori kepemimpinan diri (self-leadership) yang pertamakali diperkenalkan oleh Manz (1992 dalam Neck \& Milliman, 1994). Dimensi TSL meliputi; (1) manajemen diri yang berupa dialog dalam diri seorang individu (kita menganali diri kita yang tersembunyi), (2) imajinasi mental berupa kreasi, intiasari dan pengalaman simbolik akan perilaku imajinasi sebelum perilaku itu terjadi, (3) keyakinan dan asumsi yang menjadi dasar proses berpikir. Tahap-tahap penerapan strategi TSL sebagai berikut;

1. Tahap observasi dan pencatatan tentang tiga dimensi TSL (keyakinan dan asumsi, self-talk, imajinasi mental)

2. Tahap analisa tiga dimensi TSL

3. Tahap pengembangan dan penggantian ketiga dimensi dengan yang baru

4. Membangun cara pikir dan persepsi tentang pekerjaan

5. Peningkatan nilai spiritualitas di tempat kerja

6. Perbaikan kinerja karyawan dan perusahaan.

Pada tahun 1980, Alvin Toffler pernah menyatakan bahwa faktor terpenting yang menggerakkan organisasi adalah teknologi. Sedangkan saat ini, terdapat gerakan keempat dalam perubahan organisasi yakni nilai spiritualitas (Marsh \& Conley, 1999). Lebih lanjut, Marsh dan Conley menyatakan bahwa perusahaan yang ingin berhasil mengelola nilai spiritualitas perlu memperhatikan enam kunci penting yang meliputi; jujur terhadap diri sendiri, memperjelas filosofi nilai spiritualitas yang dimiliki perusahaan, saling menguntungkan dan mempercayai pihak lain, komitmen terhadap kualitas dan pelayanan, komitmen terhadap karyawan, dan menyeleksi karyawan yang sesuai dengan filosofi yang dianut perusahaan.

\section{KESIMPULAN}

Program training \& developmen dilaksanakan untuk mendorong karyawan dan pegawai guna mencapai standar kerja yang tinggi sehingga kinerja organisasi meningkat. 
Perubahan keterampilan, sikap dan perilaku merupakan tujuan inti kegiatan training \& development. Salah satu kebutuhan karyawan dan pegawai yang seringkali dilupakan dan terlupakan adalah kebutuhan yang bersifat kejiwaan dan batiniah. Hal ini dapat dimaklumi, dimana saat ini paham materialisme telah menghinggapi pikiran dan jiwa umat manusia. Namun seiring dengan perkembangan ilmu pengetahuan dan kesadaran muncul gerakan kembali kepada nilai-nilai yang bersifat non-material, yakni sesuatu yang tersembunyi (istilah dari Maslow) kembali pada nilai spiritualitas.

Dalam program pengembangan sumberdaya manusia, nilai-nilai spiritualitas terbukti mampu dan dapat memberikan kontribusi yang positif terhadap pencapaian kinerja organisasi dan perusahaan. Riset yang dilakukan oleh Milliman et.al. menunjukkan peran penting nilai spiritualitas mampu merubah sikap dan perilaku pegawai dan karyawan. Oleh karena itu, progam training \& development perlu memasukkan dimensi spiritualitas dalam kegiatan dan metodenya. Karena dimensi spiritual yang seringkali terabaikan dalam pemenuhan kebutuhan.

\section{DAFTAR PUSTAKA}

Cacioppe, Ron. 2000. Creating Spirit at Work: Re-visioning Organization Development and Leadership. The Leadership and Organization Development Journal, Vol. 21, No. 1.

Covey, Stephan R. 1994. The Seven Habits of Highly Effective People. Jakarta: Binarupa Aksara.

Desimone, Randy L, et. al. 2005. Human Resource Development Third Edition. South-Western: Thompson.

Fencick,Tara \& Lange, Elizabeth. 1998. The Turn to the Sipritual in Workplace Training and Development. Canadian Journal for the Study of Adult Education, Vol. 12, No. 1, pp.63-87.

Howard, Sue. 2002. A Spiritual Perspective on Learning in Workplace, Journal of Managerial Psychology, Vol. 17, No.3.

Leonard, Barbara and Biberman, Jerry. 2007. Utilizing Multi-Dimensionality in the workplace: a meta study. Managerial Finance, Vol. 33, No. 12.

Makki, Alicia. 2005. The Relationship Between Spirituality and Successful Aging among Older Minority Women. Unpublished Research.

Marsh, Fraya Wegner and Conley, James. 1999. The Fourth Wave: Spritually Based-Firm, Journal of Organizational Change Management, Vol. 12, No. 4.

Milliman, John F et.al. 2003. Workplace Spirituality and Employee Work Attitude An Exploratory Empirical Assessment. Journal of Organizational Change Management, Vol. 16, No. 4.

Milliman, John F and Neck, P. 1994. Though Self Leadership Finding Spiritual Fulfilment in Organization Life. Journal of Managerial Psychology, Vol. 9, No. 6

Created with 
Rae, Leslie. 2002. The Art of Training and Development in Management (Volume 1 Effective Planning). New Delhi: Crest Publishing House.

Schaalman, Herman E. dkk. 2002. Wacana Spiritualitas Timur dan Barat. Yogyakarta: Penerbit Qolam, vi-vii.

Simamora, Henry. 2006. Manajamen Sumber Daya Manusia. STIE YKPN. Yogyakarta. 
